\title{
Antiallergic, anthelmintic and cytotoxic potentials of dried aerial parts of Acanthus ilicifolius L.
}

Pabitra Kumar Sardar, Shrabanti Dev, Md. Abdullah Al Bari, Susmita Paul, Mst. Sanzida Yeasmin, Asish Kumar Das and Nripendra Nath Biswas* (i)

\begin{abstract}
Background: Acanthus ilicifolius L. is admired for its traditional usage in the folk medicine for the treatment of numerous diseases including allergy and helminthiasis in various parts of the planet. The ethanolic extract of the aerial parts of this shrub (EEAl) was investigated in the present study for its major phytochemical groups, antiallergic activity, anthelmintic activity, cytotoxicity and for acute toxicity.

Methods: Antiallergic activity was carried out using Toluene 2, 4-diisocyanate (TDI)-induced allergic mice model by assessing various symptoms of allergic rhinitis like sneezing, scratching, swelling and watery rhinorrhea as well as counting the total and differential leukocytes profile of blood. The paralysis and death time of parasites, Haemonchus contortus (Nematoda) and Paramphistomum cervi (Trematoda) were used for anthelmintic activity test. Mortality of mice was counted to evaluate the acute toxicity whereas the mortality of brine shrimp was taken into account to assess cytotoxic potential of the extract.
\end{abstract}

Results: Phytochemical screening of the extract demonstrated the presence of alkaloids, phenolic compounds, tannins, flavonoids, glycosides, saponins, steroids and triterpenoids. Oral pretreatment of the extract significantly ameliorated the TDI-induced allergic symptoms like sneezing $(p<0.05)$, scratching $(p<0.05)$, swelling and watery rhinorrhea in experimental mice. The extract also reduced the differential count of leukocytes in the blood which was increased due to induction of allergic conditions through TDI sensitization. In anthelmintic activity test the extract revealed a dose dependent decrease in the relative index of paralysis and death for both $H$. contortus and $P$. cervi parasites and thus indicated the extract to be parasiticidal at higher concentrations. In brine shrimp lethality bioassay of toxicity assessment, the $\mathrm{LC}_{50}$ of the standard drug vincristine sulfate was $0.43 \mu \mathrm{g} / \mathrm{mL}$ whereas the extract showed the $\mathrm{LC}_{50}$ as $44.57 \mu \mathrm{g} / \mathrm{mL}$ indicating a promising cytotoxicity of the extract. In acute toxicity study the highest dose $3 \mathrm{~g} / \mathrm{kg}$ failed to show any mortality in Swiss albino mice and thus confirmed the safety of the extract for in vivo administration.

Conclusions: The present study corroborated the traditional uses of the aerial parts of Acanthus ilicifolius L. in allergic diseases and in helminthiasis.

Keywords: Acanthus ilicifolius, Antiallergic, Anthelmintic, Cytotoxicity, Acute toxicity

\footnotetext{
* Correspondence: nnathbiswas@gmail.com

Phytochemistry and Pharmacology Research Laboratory, Pharmacy Discipline,

Life Science School, Khulna University, Khulna 9208, Bangladesh
} 


\section{Background}

Mankind, from antiquity, has continuously searched curing agents to various maladies and practiced the use of different medicinal plants as a remedy thereof. Conforming to some estimates, medicinal plants have served, directly or indirectly, as the source of about $80 \%$ of the present day medicines [1] and have been explored due to having strong pharmacological activity, less adverse pharmacological effects and due to lower costs [2]. Among the pharmacological activities, antiallergic activity is crucial as the prevalence of allergic diseases is significantly increasing around the planet [3]. Allergic rhinitis, affecting $5-22 \%$ of the global population, is one of the most common allergic diseases in the world [4]. Helminthic manifestation, due to high prevalence particularly in third-world countries, is a major health problem associated with several severe complications like anemia, malnutrition, dysentery etc. resulting from this infection [5]. Although the second-generation antihistamine drugs, used for the treatment of allergic rhinitis, itching, urticaria etc., are devoid of the major adverse effects of first-generation antihistamines, nevertheless those drugs have several adverse effects including somnolence, headache, appetite simulation, body-weight gain, cardiac arrhythmia etc. [6]. Again, most of the currently available anthelmintic drugs, though less frequently, exhibit various adverse effects including fatigue, drowsiness, insomnia, headache, dizziness, rashes, hallucinations, Stevens-Johnson syndrome, tinnitus etc. [7]. This situation has prompted researchers to investigate new antiallergic and anthelmintic drugs [8].

Acanthus ilicifolius Linn. (Family: Acanthaceae) is an around $2 \mathrm{~m}$ tall shrub, having somewhat elongated to oval shaped leaves [9], with about $4 \mathrm{~cm}$ long, light blue, sessile flowers and up to $3 \mathrm{~cm}$ long, brown-colored capsule fruits [10]. It is a true mangrove species abundantly found in estuaries, from Bangladesh, India to Polynesia of Asian tropics and northern Australia [11].

Various parts of Acanthus ilicifolius L. have been used in the treatment of a wide range of ailments. In ethnomedical practices, the leaves of the plant are used, in different parts of the world, for the treatment of asthma, rheumatism, paralysis and snakebite [12-14]. Its roots have been used traditionally as antidote, expectorant, nervine tonic, and in the treatment of general debility, neuralgia, leucorrhoea, asthma, paralysis, dropsy, strangury, rheumatism, and psoriasis [15-18]. Folklore claims for this plant in Indian and Chinese system of traditional medicine are usage as diuretic, blood purifier, aphrodisiac, in treating asthma, backache, diabetes, dyspepsia, excitation, gastralgia, hepatitis, leprosy, leucorrhoea, leukemia, malignant-tumors, neuralgia, paralysis, ringworm, rheumatism, allergic skin diseases, snakebite, stomach pain, and swelled spleen [15-17, 19, 20]. Moreover, the bark-extracted water is used as antiseptic and to treat cold allergy and dermatitis in Thailand $[15,20]$.

The plant has been reported to have antioxidant [21-23], anti-inflammatory [12, 24, 25], antinociceptive [26], anticancer [27, 28], antiasthmatic [29], antimicrobial [30, 31] antidiabetic [32], antiprotozoal [33, 34], cytotoxic (activity of flower extract) [22], gastroprotective [35], hepatoprotective [13, 36], hypercholesterolemic [37, 38], antihyperglycemic [39], osteoblastic activity [40] and activity against neurological disorders [41].

Scientific investigations claimed the plant to contain a wide range of compounds including, Alkaloids, e.g. Acanthicifoline [42], Trigonellin [43], Benzoxazin-3-one [44], Benzoxazinoid glucosides [45], 4-O-b-D-glucopyranosyl-benzoxazolin-2(3$\mathrm{H})$-one [46]; Flavonoids, e.g., Quercetin, quercetin 3-O- $\beta$-Dglucopyranoside [44], Acacetin $7-\mathrm{O}-\alpha-\mathrm{L}$ rhamnopyranosyl-(1"'6")-O- $\beta$-D-glucopyranoside [47]; Aliphatic glycosides, e.g., Ilicifolioside B [48], Ilicifolioside C [49]; Lignan glycosides, e.g., (+)-Lyoniresinol 3a-[2-(3,5-dimethoxy-4-hydroxy)-benzoyl]-O- $\beta$-glucopyranoside, $\left(8 \mathrm{R}, 7^{\prime} \mathrm{S}, 8^{\prime} \mathrm{R}\right)-5,5^{\prime}$-dimethoxylariciresinol4-O- $\beta$-D-glucopyranoside, Acanfolioside, Alangilignoside $\mathrm{C}[50],(+)$-lyoniresinol 2a-O- $\alpha$-D-galactopyranosyl-3a-O- $\beta$-D-glucopyranoside, (+)-lyoniresinol 3aO- $\alpha$-D-galactopyranosyl-(1-6)- $\beta-\mathrm{D}$ glucopyranoside [51]; Megastigmane and phenolic glycosides, e.g., (Z)-4-coumaric acid 4-O- $\beta-\mathrm{D}$ glucopyranoside [48]; (6R,7E,9R)-9-hydrox$\mathrm{y}$-megastigman-4,7-dien-3-one-9-O- $\beta$-D glucopyranoside [47], 2,6-dimethoxy-p-hydroquinone 1-O- $\beta$-D-glucopyranoside, syringic acid $O-\beta$-D-glucopyranosyl ester [50], 5,11-epoxymegastigmane glucoside [52]; Phenylethanol glycosides, e.g., ilicifolioside A, ilicifolioside D [48, 53]; Triterpenoids, e.g., lupeol, oleanolic acid and ursolic acid [44, 54, 55]; Steroids e.g., stigmasterol, stigmast-7-en-3 $\beta$-ol, stigmasteryl $\beta$-D glucopyanoside [44]; Miscellaneous, 7-chloro(2R)-2-O- $\beta$-D-glucopyranosyl-2H-1,4-benzoxazin-3(4H)-one [50] etc.

While Acanthus ilicifolius L. enjoys its traditional uses in curing skin allergies in Thailand in their traditional medicinal system, $[15,19,20,55]$ or in helminthiasis $[12,56]$, or in treatment of cancer and in many other diseases, no scientific evidence is so far available on the antiallergic, anthelmintic or cytotoxic activities of aerial parts of the plant. Moreover, phenolic antioxidant constituents being associated with antiallergic property [57], due to the presence of lots of phenolic antioxidant constituents in the plant, the present study was designed and conducted to assess the antiallergic, anthelmintic and cytotoxic activity of aerial parts of Acanthus ilicifolius L. In addition, an acute toxicity study was also carried out to assess the toxicity profile of $A$. ilicifolius L. aerial parts.

\section{Materials and methods}

\section{Plant materials}

The aerial parts (leaves and stems) of Acanthus ilicifolius were collected from the Sunderbans of Satkhira region 
of Bangladesh, in May, 2015. The plant materials were taxonomically authenticated by experts at Bangladesh National herbarium, Mirpur, Dhaka, where a voucher specimen (Accession no. DACB 43824) was submitted as future reference. The collected plant part were separated from undesirable materials or plants or plant parts, were washed with water and shade-drying was carried out to remove moisture from those. The dried plant materials were then crushed into coarse powder with the help of a suitable grinder (Capacitor start motor, Wuhu motor factory, China). The powdered plant materials were then dried in an electrical drier for $2 \mathrm{~h}$ at $45^{\circ} \mathrm{C}$, kept in an airtight container to avoid fungal contamination and stored in a cool dark and dry place.

\section{Preparation of extract}

Powdered plant materials were macerated with 95\% ethanol for fourteen days and periodic shaking was carried out to ensure optimum maceration. Cotton plug and Whatman filter paper was used as filtering media to obtain a clear solution through the removal of plant debris. The ethanolic crude extract of aerial parts of A. ilicifolius (EEAI), obtained following the evaporation of ethanol in a rotary evaporator at $50^{\circ} \mathrm{C}$, was stored at $4{ }^{\circ} \mathrm{C}$ in refrigerator (Yield: $9.6 \%$ of dried plant material). To ensure optimum release profile in experimental animals, the crude extract was brought to room temperature before further experimental use.

\section{Chemicals and reagents}

TDI and standard antihistamine drug cetirizine were obtained from Wako Chemical, Tokyo, Japan. Standard albendazole, Tween-80, vincristine sulphate and dimethyl sulfoxide (DMSO) were purchased respectively from Beximco Pharmaceuticals Ltd., Dhaka, Bangladesh, Loba Chemie, India; Cipla Pharmaceuticals India and Merck, Darmstadt, Germany. All other chemicals including sodium carbonate, ferric chloride, acetic acid, ethyl acetate etc. were of analytical grade and were purchased from Merck (Darmstadt, Germany).

\section{Experimental animals and parasites}

Young Swiss-albino mice, aged 4-5 weeks, average weight 25-30 g., were used for the present experiment. They were kept in the animal laboratory of Pharmacy Discipline, Khulna University, Khulna- 9208, and a temperature of $23 \pm 1{ }^{\circ} \mathrm{C}$ and humidity of $55 \pm 5 \%$, with 12-h light/12-h dark cycle was maintained for one week for adaptation after purchasing them from Jahangirnagar University, Bangladesh. The animals were fed standard laboratory food and tap water ad libitum. Live parasites $P$. cervi (Trematoda) and $H$. contortus (Nematode) were collected from freshly slaughtered cattle at local abattoirs. After cleaning normal saline $(0.9 \% \mathrm{NaCl})$, parasites were stored in $0.9 \%$ phosphate-buffered saline (PBS) of $\mathrm{pH}$ 7.4. All animal experiments were carried out following the guidelines of Animal Ethics Committee, Pharmacy Discipline, Life Science School, Khulna University, Bangladesh.

\section{Preliminary phytochemical screening}

Phytochemical group test of the extract was performed using standard testing methods [58] for the identification of carbohydrates/gums, reducing sugars, alkaloids, flavonoids, glycosides, steroids, triterpenoids, tannins, and saponins.

\section{Acute toxicity test}

Acute oral toxicity test was carried out according to the Organization for Economic Co-operation and Development (OECD) guidelines-425. Male Swiss albino mice were divided into seven groups containing six animals each. The control group received normal saline $(2 \mathrm{ml} / \mathrm{kg}$, orally p.o.). The other groups received 100, 200, 500, 1000,2000 and $3000 \mathrm{mg} / \mathrm{kg}$ of test extract, respectively. Immediately after dosing, the animals were observed continuously for $24 \mathrm{~h}$ for any behavioral changes and for any sign of toxicity. Neither any sign of toxicity nor death was observed within $24 \mathrm{~h}$. The animals were then observed for next 14 days with an interval of $24 \mathrm{~h}$ to find out the mortality $[59,60]$ or any other toxic responses.

\section{Antiallergic activity test \\ Antigen for sensitization and provocation}

Toluene 2, 4-diisocyanate (TDI) was used as antigen for sensitization and provocation of allergy and was prepared at a concentration of 5\%, in ethyl acetate solvent.

\section{TDI sensitization and provocation of animals}

Antiallergic activity of aerial parts extract of $A$. ilicifolius L. was assessed on adult male Swiss albino mice according to procedures of Dev et al. with minor modifications [61-63]. After acclimatization with the standard housing conditions of the animal house, fifty adult Swiss albino male mice were randomly selected and divided into five groups (10 in each group) denoted as group-I, group-II, group-III, group-IV and group-V. Group-I (Control) received ethyl acetate $(10 \mu \mathrm{L})$ bilaterally in the nasal vestibules and $2 \%$ aqueous solution of tween- 80 water orally. Group-II served as TDI control and received TDI $(10 \mu \mathrm{L}$ of 5\% TDI in ethyl acetate) bilaterally in the nasal vestibules and $2 \%$ tween- 80 water equivalent to the vehicle given with the extract orally. Group-III served as standard group and was given TDI $(10 \mu \mathrm{L}$ of $5 \%$ TDI solution in ethyl acetate) bilaterally in the nasal vestibules and an antihistamine drug, cetirizine, at a dose of $20 \mathrm{mg} / \mathrm{kg}$ body weight orally. Group-IV and group-V received ethanolic extract of A. ilicifolius (300 mg/kg and $500 \mathrm{mg} /$ $\mathrm{kg}$ body weight respectively) orally and TDI (10 $\mu \mathrm{L}$ of $5 \%$ 
TDI solution in ethyl acetate) bilaterally in the nasal vestibules.

All the mice (except Group-I) were sensitized, with $10 \mu \mathrm{L}$ of $5 \%$ TDI in ethyl acetate, bilaterally on the nasal vestibule of each mice, once a day for five consecutive days [63]. After an interval of two days, the same sensitization procedure was then repeated. Following nine days of the second sensitization (on 21st day of the experimental protocol), for provoking nasal allergy-like symptoms, $10 \mu \mathrm{L}$ of $5 \%$ TDI solution was again applied to the nasal vestibule of the experimental animals (except Group-I). The control group (Group-I) was sensitized and provoked with $10 \mu \mathrm{L}$ of ethyl acetate only, according to the same procedure. Group-IV and group-V received ethanolic extract of $A$. ilicifolius, at the dose of $300 \mathrm{mg} / \mathrm{kg}$ and $500 \mathrm{mg} / \mathrm{kg}$ respectively, once a day throughout the entire experiment, and was continued even during the interval period. The extracts were administered $1 \mathrm{~h}$ prior to TDI application. Group-III received cetirizine at a dose of $20 \mathrm{mg} / \mathrm{kg}$ body weight, only on the 21 st day just $1 \mathrm{~h}$ before TDI provocation (Fig. 1).

\section{Assessment of allergy-like symptoms}

Nasal allergy-like symptoms including the number of sneezes, number of scratches (rubbings), the nasal scores, the extent of watery rhinorrhea were measured following the methods described previously [63-65]. Immediately after TDI provocation, the number of sneezes, number of scratching and severity of watery rhinorrhea were carefully assessed for each group for $10 \mathrm{~min}$, by placing the animals in various cages (ten animals per cage). The extent of watery rhinorrhea was measured on a grading scale ranging from 0 to 3 (Table 1), where 0 is lowest and 3 is highest.

\section{Blood collection and blood cell count}

On 21st day of that experimental period, the nasal allergy-like symptoms were assessed and $24 \mathrm{~h}$ following provocation with $5 \% \mathrm{TDI}$, animals of each group were anesthetized by injecting sodium pentobarbital and blood sample was collected from the cervical vein as methods described by Mahajan et al., 2007 and Smita et al., $2014[62,66]$. The collected blood was then placed in a heparinized tube and used for total and differential leukocyte count. Total leukocytes were counted after the blood was diluted at 1:10 ratio with $1 \%$ acetic acid to lyse red blood cells. Total blood cell counts were then carried out on automated cell counter (DS-500i, 5 part automated hematology analyzer; Edan Instruments Inc., Shenzhen, China). For determining differential counts of blood cells, slides were prepared and were then stained with Leishman stain. Following drying of the slides, 300 cells/slide were counted on a compound microscope oil immersion power at $400 \times$ magnification. In order to carry out differentials, using standard morphological determinants, cells were identified as eosinophils, lymphocytes, monocytes, neutrophils or basophils.

\section{Anthelmintic activity test}

Anthelmintic activity of the extract was assessed on live parasites $P$. cervi and $H$. contortus of cattle $[5,67,68]$. First off, the collected parasites were divided into six groups consisting of six parasites in each group. The extract was prepared at concentrations of 25,50,100, and $200 \mathrm{mg} / \mathrm{mL}$ of $10 \mathrm{~mL}$ in phosphate buffered saline (PBS). Standard albendazole was prepared at the concentration of $15 \mathrm{mg} / \mathrm{mL}(10 \mathrm{~mL})$ in PBS and was used as reference drug. Tween- 80 of $0.1 \%$ concentration in PBS was used to treat control group. All the extracts, reference drug and control was then transferred to Petri dishes. Six

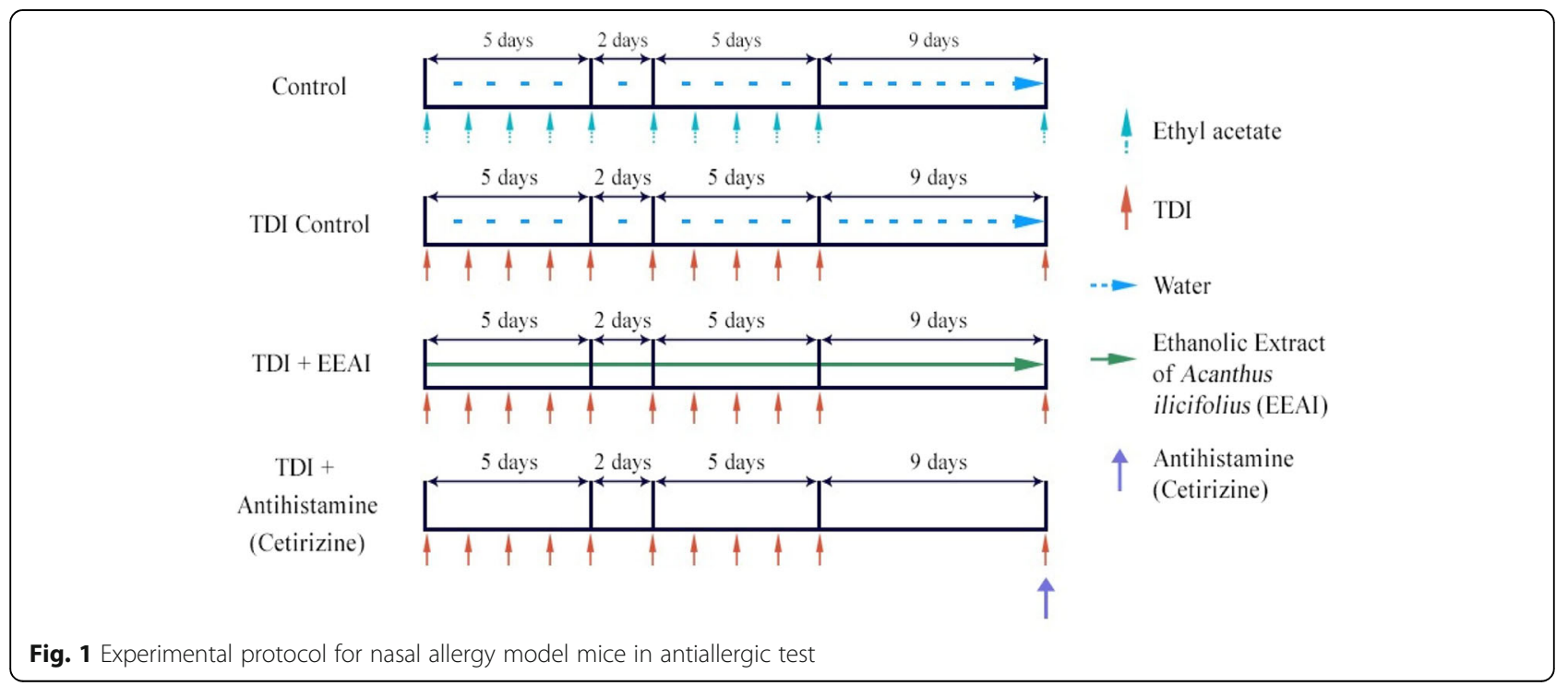


Table 1 Criteria for grading the severity of TDI-induced nasal responses in mice

\begin{tabular}{|c|c|c|c|c|}
\hline \multirow[t]{2}{*}{ Nasal Response } & \multicolumn{4}{|c|}{ Score } \\
\hline & $\overline{0}$ & 1 & 2 & 3 \\
\hline Watery rhinorrhea & - & At the nostril & Between 1 and 3 & Drops of discharges \\
\hline Swelling and redness & - & Slightly swollen & Between 1 and 3 & Strong swelling with redness \\
\hline
\end{tabular}

parasites were placed in each Petri dish and observed for mobility or death. When no movement of the parasites was observed unless shaken vigorously, that time was recorded as time of paralysis. Again, when the parasites did not move as shaken vigorously, dipped in warm water of $50^{\circ} \mathrm{C}$, or subjected to external stimuli, that time was taken to note as death time. The time required for paralysis and death of parasites when compared to control was used to express anthelmintic activity of the extract. The experiment was triplicated to avoid statistical error.

\section{Cytotoxic activity test}

The general cytotoxicity of the ethanolic extract of the plant was tested using brine shrimp lethality bioassay [69]. Simulated sea water $(3.8 \% \mathrm{NaCl}$ in water) was prepared, dissolving $38 \mathrm{~g} \mathrm{NaCl}$ in $1 \mathrm{~L}$ of double-distilled water. Brine shrimp (Artemia salina) eggs were hatched using a conical shaped vessel containing previously prepared $1 \mathrm{~L}$ artificial seawater at $25-30{ }^{\circ} \mathrm{C}$ temperature with a constant oxygen supply. The Artemia salina eggs took about $24-48 \mathrm{~h}$ to be hatched. The larvae (nauplii) were collected using a pipette. Dimethyl sulfoxide (DMSO, 1\%) was used to dissolve the sample extract and the extract was then transferred into seven test tubes following the method of serial dilution in such way that each test tube contained $10 \mathrm{~mL}$ of artificial sea water having seven different sample concentrations viz. 400, 200, 100, 50, 25, 12.5 and $6.25 \mu \mathrm{g} / \mathrm{mL}$. Ten nauplii were placed in each test tube. DMSO (1\%) was added to seven test tubes and Vincristine sulphate, an anticancer drug, was used as the positive control following the method of serial dilution in such way that each test tube contained $10 \mathrm{~mL}$ of artificial sea water having seven different vincristine sulphate concentrations at 10, 5, 2.5, $1.25,0.625,0.312,0.156 \mu \mathrm{g} / \mathrm{mL}$. Again, ten nauplii were placed in each test tube of positive control group. A negative control group was also tested with 10 nauplii in $10 \mathrm{~mL}$ sea water containing DMSO (1\%). Following the period of $24 \mathrm{~h}$ at room temperature, the number of viable nauplii were counted. The experiment was triplicated to avoid statistical error.

\section{Statistical analysis}

Results were expressed as mean \pm S.D. (Standard Deviation). All statistical analysis were carried out using Student's t-test. Statistical analysis and graphics generation were accomplished using GraphPad Prism ${ }^{\bullet} .03$ (GraphPad software
Inc., San Diego, CA). Results were considered as significant when $p<0.05$. The $\mathrm{LC}_{50}$ value in brine shrimp lethality bioassay was determined using Ldp line probit analysis software, USA.

\section{Results}

Preliminary phytochemical screening

Various phytochemicals tests conducted on the extract indicated the presence of alkaloids, steroids, terpenoids, saponins, tannins, phenolic compounds, glycosides and flavonoids and the absence of reducing sugars and carbohydrates (Table 2).

\section{Acute toxicity test}

Acute toxicity study revealed the non-toxic nature of the extracts. There was no lethality or any toxic reactions found at any of the doses even at $3000 \mathrm{mg} / \mathrm{kg}$ until the end of the study period, suggesting the $\mathrm{LD}_{50}$ of the extract of the plant is above $3000 \mathrm{mg} / \mathrm{kg}$.

\section{Antiallergic activity test \\ Effect on TDI-induced nasal allergy-like symptoms}

In the mice of TDI-control group (Group II), the total number of sneezes (Fig. 2b), scratching (rubbing) (Fig. 2b) and nasal score (Fig. 2c) were $30.1 \pm 15.35$, $195.63 \pm 50.95$ and $3.00 \pm 0$ respectively. Whereas the

Table 2 Results of phytochemical group test of the extract

\begin{tabular}{|c|c|c|}
\hline $\begin{array}{l}\text { Tests for phytochemical } \\
\text { groups }\end{array}$ & Reagents/Tests & Results $^{a}$ \\
\hline \multirow[t]{2}{*}{ Reducing sugar } & Fehling's test & - \\
\hline & Benedict's test & - \\
\hline Gum/Carbohydrate & Molish's test & - \\
\hline Alkaloids & Dragendorff's test & + \\
\hline \multirow[t]{2}{*}{ Steroids and terpenoids } & Salkowski's test & + \\
\hline & Libermann-Burchard reagent & + \\
\hline Saponins & Frothing test & + \\
\hline \multirow[t]{2}{*}{ Flavonoids } & Shinoda test & + \\
\hline & Alkaline reagent test & + \\
\hline Tannins & Ferric chloride test & + \\
\hline \multirow[t]{2}{*}{ Glycosides } & $\begin{array}{l}\text { Borntrager's test } \\
\text { (Anthraquinone } \\
\text { glycosides) }\end{array}$ & + \\
\hline & $\begin{array}{l}\text { Keller Killiani test } \\
\text { (cardiac glycoside) }\end{array}$ & + \\
\hline
\end{tabular}

${ }^{a}+$ indicates presence and - indicates absence 


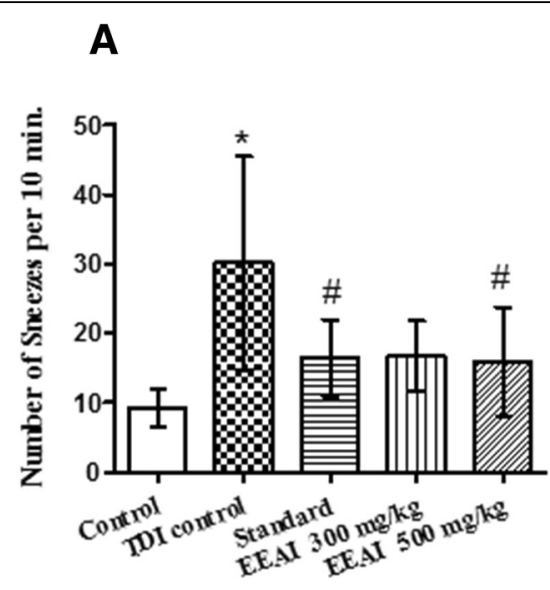

Treatment Groups
B

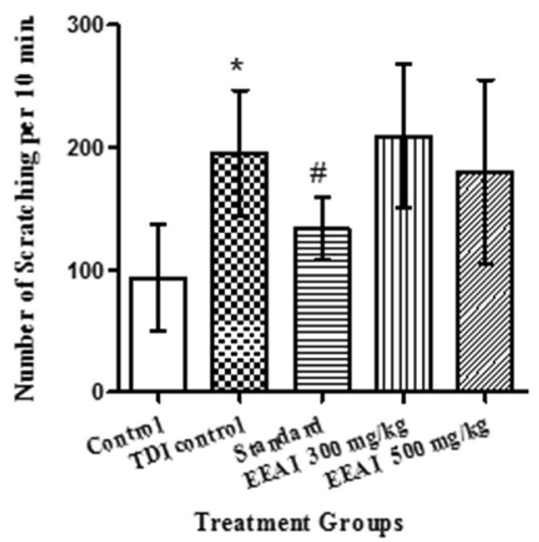

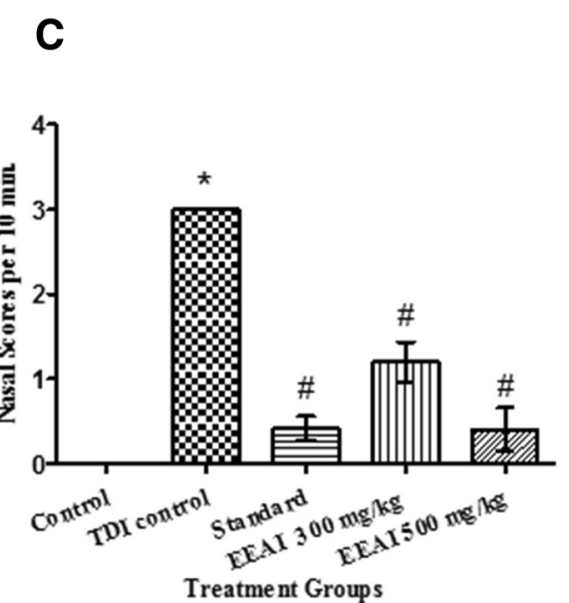

Fig. 2 a, b, c Suppressive effect of A. ilicifolius extract on Sneezing (a), Nasal Scratching (b) and Nasal Score (c). Values are expressed as Mean \pm S.D., $n=10$; * $p<0.05$ vs. Control; \#p<0.05 vs. TDI Control

number of sneezes, scratching and nasal score, for standard cetirizine were $16.37 \pm 5.57,133.3 \pm 25.51$ and $0.4 \pm 0.28$; for $300 \mathrm{mg} / \mathrm{kg}$ dose of the extract those values were $16.67 \pm 5.04,209.0 \pm 59.07$ and $1.2 \pm 0.23$; and for $500 \mathrm{mg} / \mathrm{kg}$ dose of the extract those values were $15.87 \pm 7.82$, $180.3 \pm 75.21$ and $0.4 \pm 0.25$. As such, oral pre-treatment of ethanolic extract of A. ilicifolius for 3 weeks, significantly decreased the number of sneezes, and nasal score and the efficacy of extract was comparable with the standard antihistamine drug, cetirizine, in case of sneezes and nasal score at the dose of $500 \mathrm{mg} / \mathrm{kg}$ (Fig. 2a, b, c).

\section{Effect on circulating total blood cell (leukocyte) count and differential blood cell count}

In the blood samples of the mice of TDI-control group, the total numbers of circulating leukocytes, eosinophils, lymphocytes, neutrophils, monocytes and basophils were markedly increased $(p<0.05)$ in comparison with that of the mice of Control group. In contrast, the numbers of total leukocytes, eosinophils lymphocytes, neutrophils, monocytes and basophils were decreased in the blood samples of mice treated with ethanolic extract of A. ilicifolius L. and in mice treated with standard cetirizine, as compared to those levels in TDI-control group mice. The efficacy of the extract at the dose of $500 \mathrm{mg} / \mathrm{kg}$ was comparable with standard cetirizine $(20 \mathrm{mg} / \mathrm{kg})$ (Fig. 3).

\section{Anthelmintic activity test}

In a concentration-dependent manner, the aerial part extract exhibited significant anthelmintic activity which was comparable with standard drug albendazole. The results are presented in Table 3. In P. cervi, both paralysis and death occurred faster at higher concentrations of the extract (i.e. $5.50 \pm 2.42 \mathrm{~min}$ and $10.17 \pm 2.71$ at 200 $\mathrm{mg} / \mathrm{mL}$ ). In $H$. contortus, a similar tendency was found (i.e. $9.33 \pm 3.82 \mathrm{~min}$ and $18.83 \pm 3.54$ at $200 \mathrm{mg} / \mathrm{mL}$ ). Again, the relative index values of paralysis obtained were $2.93,1.84,1.15$ and 0.55 for $P$. cervi and 2.03, 1.30, 0.65 and 0.48 for $H$. contortus at concentrations of 25 , 50, 100 and $200 \mathrm{mg} / \mathrm{mL}$ of the extract, respectively, vs. 


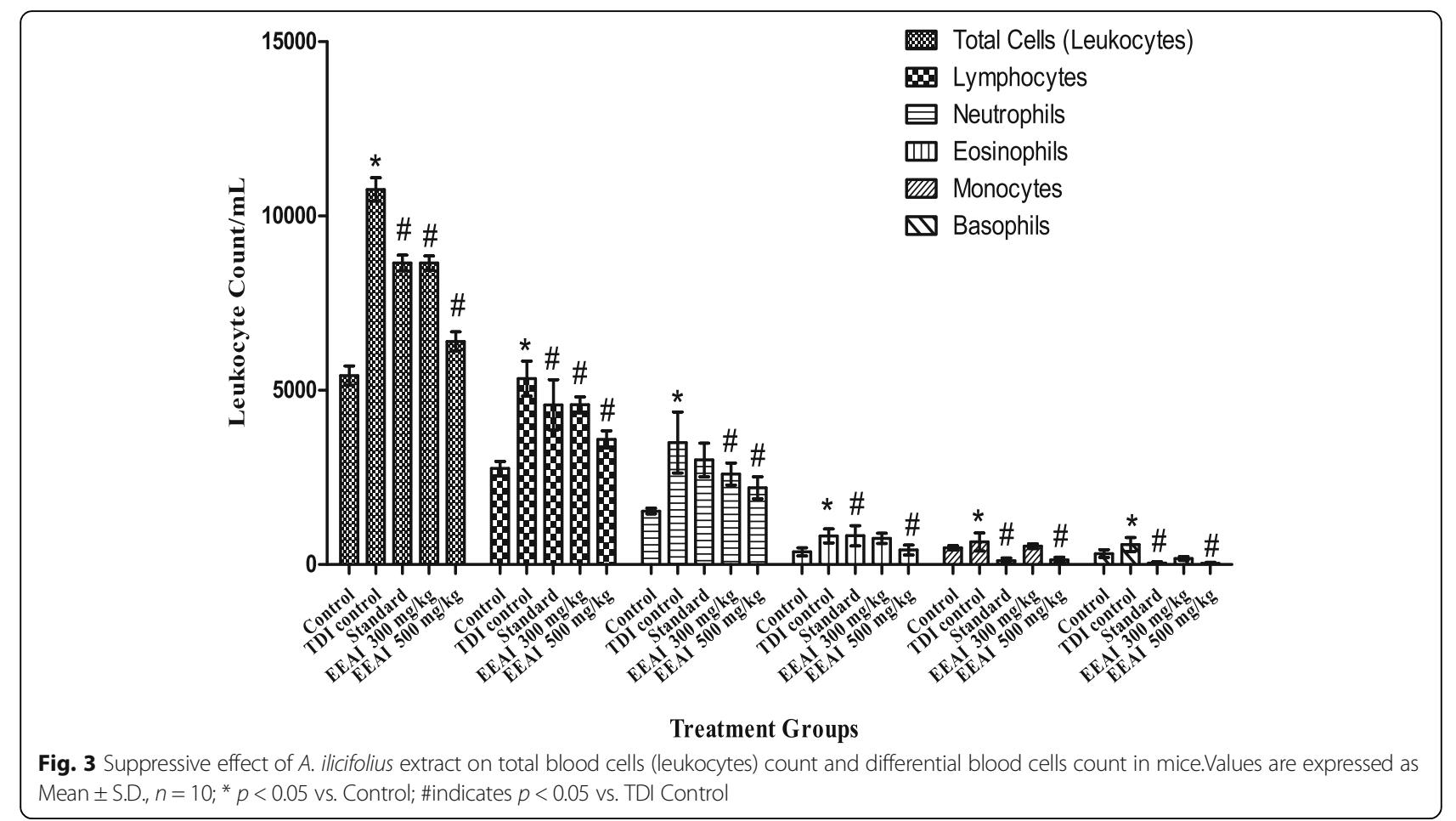

albendazole $(15 \mathrm{mg} / \mathrm{mL})$. By contrast, the relative index values for death in $P$. cervi were $2.03,1.30,0.65$, and 0.48 and that in $H$. contortus were $1.69,1.10,0.69$ and 0.60 at concentrations of $25,50,100$ and $200 \mathrm{mg} / \mathrm{mL}$ of the extract, respectively, vs. albendazole $(15 \mathrm{mg} / \mathrm{mL})$. These data suggest that the anthelmintic activity of the extract at high concentration is comparable with albendazole.

\section{Cytotoxic activity test}

The extract exhibited lethality on brine shrimp in a dose dependent manner. The $\mathrm{LC}_{50}$ for ethanolic extract of $\mathrm{A}$. ilicifolius was found to be $44.57 \mu \mathrm{g} / \mathrm{mL}$ whereas that of standard anticancer drug vincristine sulphate was $0.42 \mu \mathrm{g} / \mathrm{mL}$ (Fig. 4a, b). Data set have been presented in Table 4.

\section{Discussion}

Evaluating the anti-allergic potential of ethanolic extract of aerial parts of $A$. ilicifolius L. on TDI-induced allergic rhinitis in Swiss albino mice was the objective of this study. The investigation was carried out on an established animal model in which mice were sensitized and provoked with TDI for inducing the onset of allergy-like symptoms, e.g., sneezing, rhinorrhea, nasal blockage, redness, swelling, scratching (rubbing), differential cell infiltration into tissues of lungs and airways, eosinophilia and release of biochemical substances like interleukins (IL)-4, IL-6 etc. $[62,63]$. In this study, we showed that ethanolic extract of aerial parts of A. ilicifolius L. exhibits symptomatic relief of allergic rhinitis in mice. $A$.

Table 3 Anthelmintic activity of different doses of Acanthus ilicifolius L.aerial parts against P. cervi and H. contortus

\begin{tabular}{|c|c|c|c|c|c|c|c|c|c|}
\hline \multirow[t]{4}{*}{ Groups } & \multirow{4}{*}{$\begin{array}{l}\text { Concentrations } \\
\text { (mg/mL in PBS) }\end{array}$} & \multicolumn{8}{|l|}{ Test Parasites } \\
\hline & & \multicolumn{4}{|c|}{ Paramphistomum cervi } & \multicolumn{4}{|c|}{ Haemonchus contortus } \\
\hline & & \multicolumn{2}{|l|}{ Paralysis } & \multicolumn{2}{|l|}{ Death } & \multicolumn{2}{|l|}{ Paralysis } & \multicolumn{2}{|l|}{ Death } \\
\hline & & $\begin{array}{l}\text { Time } \\
\text { taken (min) }\end{array}$ & $\begin{array}{l}\text { Relative } \\
\text { index }^{a}(P)\end{array}$ & $\begin{array}{l}\text { Time } \\
\text { taken (min) }\end{array}$ & $\begin{array}{l}\text { Relative } \\
\text { index (D) }\end{array}$ & $\begin{array}{l}\text { Time } \\
\text { taken (min) }\end{array}$ & $\begin{array}{l}\text { Relative } \\
\text { index }(P)\end{array}$ & $\begin{array}{l}\text { Time } \\
\text { taken (min) }\end{array}$ & $\begin{array}{l}\text { Relative } \\
\text { index (D) }\end{array}$ \\
\hline Control & 0 & - & - & - & - & - & - & - & - \\
\hline EEAI 25 & 25 & $28.83 \pm 1.72$ & 2.93 & $34.83 \pm 3.18$ & 2.24 & $39.00 \pm 5.09$ & 2.03 & $53.17 \pm 7.02$ & 1.69 \\
\hline EEAI 50 & 50 & $18.16 \pm 1.94$ & 1.84 & $23.00 \pm 2.60$ & 1.48 & $25.00 \pm 4.93$ & 1.30 & $34.67 \pm 4.96$ & 1.10 \\
\hline EEAI 100 & 100 & $11.33 \pm 1.86$ & 1.15 & $13.16 \pm 2.04$ & 0.84 & $12.50 \pm 4.46$ & 0.65 & $21.67 \pm 5.50$ & 0.69 \\
\hline EEAI 200 & 200 & $5.50 \pm 2.42$ & 0.55 & $10.17 \pm 2.71$ & 0.65 & $9.33 \pm 3.82$ & 0.48 & $18.83 \pm 3.54$ & 0.60 \\
\hline Albendazole & 15 & $9.83 \pm 1.47$ & 1.00 & $15.50 \pm 2.66$ & 1.00 & $19.17 \pm 4.02$ & 1.00 & $31.33 \pm 6.62$ & 1.00 \\
\hline
\end{tabular}

Values are expressed as Mean \pm S.D., $n=$ number of parasites (6), ${ }^{2}$ Relative index denotes the time taken for paralysis (P) or death (D) to occur for EEAl/the time taken for paralysis or death to occur for the standard albendazole 


\section{A}

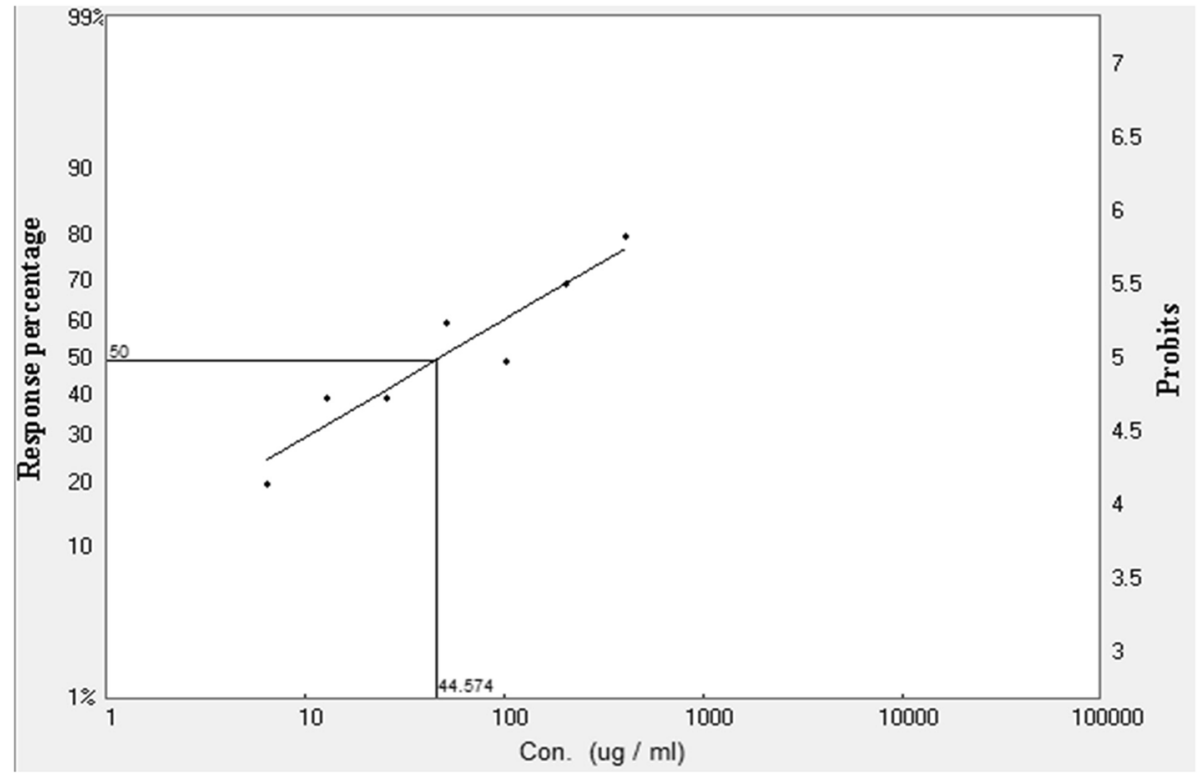

B

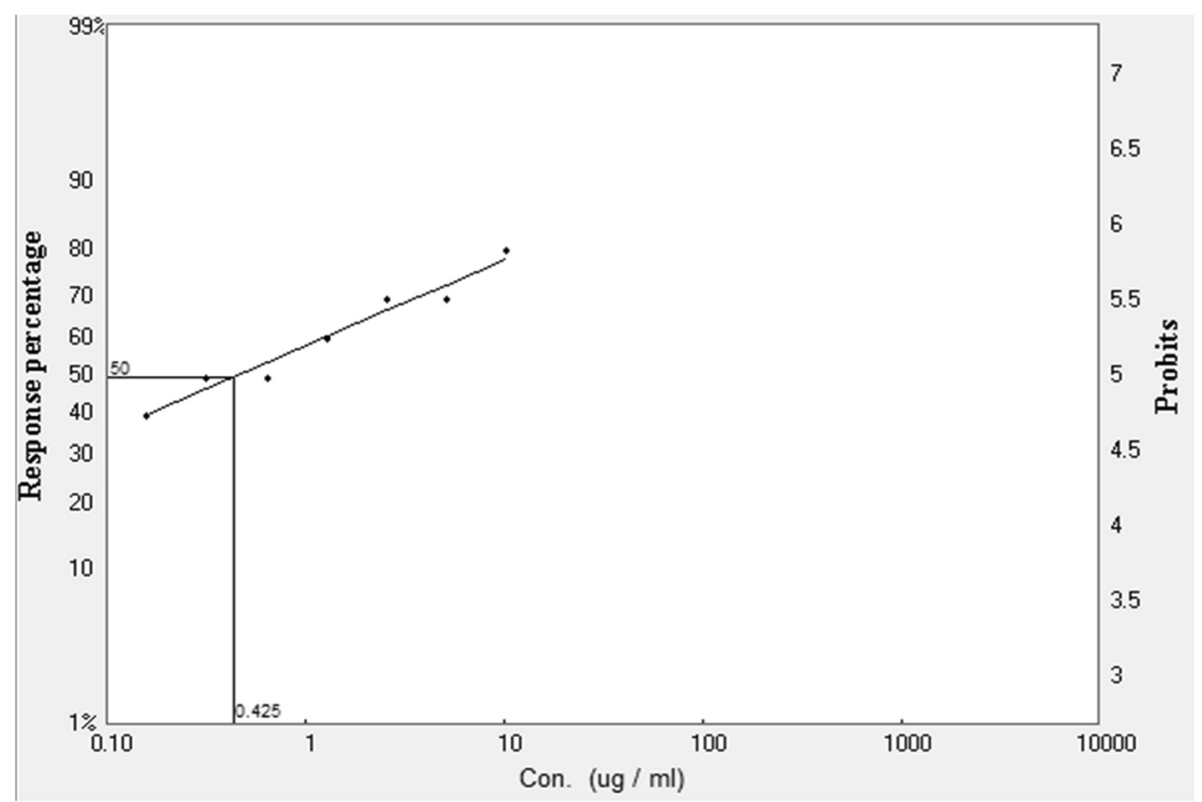

Fig. 4 a, b Determination of $L C_{50}$ for the ethanolic extract of $A$. ilicifolius $L$. a and vincristine sulphate (b) using $L d p$ line software

Table $4 \mathrm{LC}_{50}$ for EEAl and standard with lower and upper limit calculated by Ldp line software

\begin{tabular}{llll}
\hline & $L_{50}(\mu \mathrm{g} / \mathrm{mL})$ & Lower limit $(\mu \mathrm{g} / \mathrm{mL})$ & Upper limit $(\mu \mathrm{g} / \mathrm{mL})$ \\
\hline EEAl & 44.574 & 23.338 & 81.640 \\
Standard & 0.424 & 0.234 & 0.645 \\
\hline
\end{tabular}


ilicifolius L. extract significantly suppressed sneezing and nasal score as shown in Fig. 2a, b, c. It also decreased the nasal rubbing (scratching), but that was not significant. Suppression of these allergy-like symptoms (Fig. 2a, b, c) prompted us to study whether the extract has any effect on cells associated with inflammation and on the total and differential blood cell count in TDI-induced allergy model mice $[8,63]$. In addition, in our study we have found increase in levels of total leukocytes, eosinophils, lymphocytes neutrophils, monocytes and basophils in blood of TDI-control mice (Fig. 3), and treatment with the ethanolic extract at an oral dose of $300 \mathrm{mg} / \mathrm{kg}$ and $500 \mathrm{mg} / \mathrm{kg}$ and cetirizine $(20 \mathrm{mg} / \mathrm{kg})$ reduced the count of these inflammatory cells as compared to TDI-control.

Mention-worthy, increased eosinophils in blood represent an overall state of allergic condition. Moreover, allergy/ asthma patients show increased eosinophilia and leukocytosis and this increased eosinophilia and leukocytosis may work as a good cellular biomarker for allergic symptoms [70, 71]. Therefore, our experimental results (Fig. 3) are consistent with hypothesis and findings presented previously by several researchers [72-74]. In addition, the significant increases in the number of total and differential leukocytes, particularly, increase in the number of eosinophils, neutrophils, lymphocytes, monocytes and basophils, in the blood of the mice in TDI Control group, found in our study, is consistent with previous data reported by researchers who induced asthma using TDI in guinea pig model [61] and in rat model [62].

Preliminary phytochemical screening exhibited that $A$. ilicifolius aerial part extracts contains alkaloids, flavonoids, glycosides, steroids, tannins, triterpenoids and saponins (Table 1). It has been reported previously that the antiallergic activity of Gymnema sylvestre $\mathrm{R} \mathrm{Br}$ is assumed to be due to the presence of tannins, total phenols, and flavonoids [74]. Histamine signaling, which is the major cause of allergic symptoms, is suppressed by several phytochemicals compounds e.g. tannins, including epigallocatechin-3-O-gallate isolated from green tea [75]. It has been reported that polyphenolic compounds e.g., gallic acid (3, 4, 5-trihydroxy benzoic acid) suppress various hypersensitivity reactions in mice and inhibit release of histamine and helper T cell cytokines, IL-4, IL-5 and IL-2 form mast cells in various experimental animal model of allergic diseases [76-78]. As A. ilicifolius extract has higher phenolic content, those could be the compounds responsible for the antiallergic effects of ethanolic extract of aerial parts of A. ilicifolius in a possibly similar mechanism. Moreover, as gallic acid is a tannin compound in chemical nature, and as A. ilicifolius extract exhibited presence of tannin in phytochemical screening, antiallergic activity of the extract could be due to the presence tannin contents in it.

Antioxidants reduce intracellular reactive oxygen species production and thus modulate both the function of mast cell as well as gene expression of IL-4 [79]. It has been reported that the antiallergic activity of the ethanolic extract of Sanseveiria trifasciata leaves is due to the presence of steroidal saponins, triterpenoids, flavonoids etc. which are known as potent antioxidants [72]. As the extract of A. ilicifolius L., in preliminary phytochemical analysis, exhibited presence of all of these compound including flavonoids, and as the extract exhibited free radical scavenging activity and possesses potent antioxidant property $[12,13,22,23]$, it is possible that these phytoconstituents either alone or combinedly, may have elicited the antiallergic activity observed in our investigation.

According to a previous scientific report, saponins inhibit degranulation of mast cells and thus inhibit histamine signaling and alleviate allergic symptoms [80]. Thus, presence of saponins in the extract exhibited in preliminary phytochemical analysis, could be responsible for the anti-allergic effect of the extract. In addition, Smita and other researchers have showed that a steroid, stigmasterol (stigmast-5, 22-dien-3 $\beta$-ol), in combination with dexamethasone (an antiallergic drug), imparts antiallergic activity which is more potent than the activity of dexamethasone alone. Thus, as A. ilicifolius L. contains stigmasterol [44] as well, the ethanolic extract of A. ilicifolius may impart its antiallergic activity through the similar mechanism [66].

Accumulating all these data, in conclusion, our experimental findings provide adequate scientific basis for traditional use of $A$. ilicifolius $\mathrm{L}$. in the treatment of allergic rhinitis. Thus, according to our experimental data, we may hypothesize that prolonged oral administration of the extract might play an important role in the management of TDI-induced allergic rhinitis.

In in vivo studies of anthelmintic activity of plant materials, loss of movement or paralysis and complete destruction or death of live parasites are usually utilized as the parameters [81-83]. In vivo anthelmintic activity of A. ilicifolius has previously been reported on adult earth worm model and worm parasite of chicken [56]. In the present work, we established significant anthelmintic activity of aerial parts of the extract of A. ilicifolius in a concentration dependent manner on freshly collected live parasites (Trematoda and Nematode) from cattle which is consistent with the earlier report by Husori and colleages. Anthelmintic activity of secondary metabolites obtained from plants have been attributed to the presence of alkaloids, flavonoids, steroids, tannins and saponins [56]. This is consistent with our data (Table 1) for the phytochemical analysis of the plant, as the preliminary phytochemical screening exhibited that A. ilicifolius extract contains alkaloids, flavonoids, steroids, tannins and saponins.

Though, too little is known regarding the precise mechanism involved with the obtained anthelmintic activity of 
the extract, a role may have been played in it by the polyphenolics or other biochemical compounds present in the extract. It has been reported, for instance, that by uncoupling oxidative phosphorylation or binding to the glycoprotein on the cuticle of parasites, tannins are capable of interfering with energy generation in helminthes parasites and thus to cause death of the parasites [84, 85]. Capability to bind with the free protein in the host animal's digestive tract has been reported as another mechanism of tannins anthelmintic activity. According to some reports, tannins contained in the plant are capable of enhancing the absorption of protein which is obtained through the formation of protein complexes in the rumen, which at the low $\mathrm{pH}$ in the small intestine break down later [86].

Moreover, flavonoids and saponins have recently been reported to have the capability of exerting anthelmintic activity. Saponins have been described to increase the membrane permeability and pores formation, both of which actions are similar to the mechanism of established anthelmintic praziquantel and toltrazuril $[87,88]$. Saponins and tannins may cause damage to the mucopolysaccharide membrane of worm which results in paralysis and death of those [89].

Furthermore, the alkaloids and steroids in the extracts may play key role in providing the suppressive effect of sucrose transfer to the small intestine which eventually can reduce glucose support for the worm parasites. These effects provided by alkaloid and steroids together with the antioxidant effects exerted by flavonoids can reduce the production of nitrate to be used in synthesis of protein [90]. Paralysis and death of parasites can possibly result from the action of alkaloid on CNS of parasites [91]. In addition, all these phytochemicals and their interaction may possibly have synergistically enhanced therapeutic efficacy of anthelmintic activity of $A$. ilicifolius aerial parts extract.

The brine shrimp lethality bioassay is an established, easy, safe, economic and practical method for predicting important pharmacological activities such as enzyme inhibition, ion channel interference, cytotoxic activity and several other bioactivities of synthetic compounds and of plant products [69, 92-94]. The significant correlation between the brine shrimp assay and human solid tumor cell lines in vitro growth inhibition demonstrated by the National Cancer Institute (NCI, USA) has shown the value of this bioassay as a pre-screening tool for antitumor drug research $[95,96]$. According to Meyer et al., natural products' extracts exhibiting $\mathrm{LC}_{50} \leq 1000 \mu \mathrm{g} / \mathrm{mL}$ in brine shrimp bioassay have been claimed to possess bioactive constituents [69]. Several criteria for toxicity in brine shrimp lethality bioassay for synthetic compounds or natural products have been established where the $\mathrm{LC}_{50}$ values above $1000 \mu \mathrm{g} / \mathrm{mL}$ are non-toxic, between 500 and $1000 \mu \mathrm{g} / \mathrm{mL}$ are weak toxic and below $500 \mu \mathrm{g} /$
$\mathrm{mL}$ are toxic [97]. In the present study, both the extract and vincristine sulphate showed a gradual increase in mortality rate with the increase of concentration. The $\mathrm{LC}_{50}$ value for the ethanolic extract of A. ilicifolius was found to be very low $(44.57 \mu \mathrm{g} / \mathrm{mL})$, signifying that the extract may contain potent pharmacologically active compound(s). The toxicity of plants is mainly attributed to the presence of alkaloids, phenolic compounds, glycosides, steroids, tannins, phlobatannins, terpenoids, flavonoids and saponins [98-101]. This is consistent with our observation as well, as the phytochemical group analysis of the extract exhibited the presence of alkaloid, tannins, flavonoid, steroids and saponins (Table 1). Thus, the principal advantage of the extract with regard to its cytotoxic effect could be exploitation of the cytotoxic potentials of A. ilicifolius for the development of natural product derived better medication for cancer.

\section{Conclusions}

The present study was carried out to evaluate the antiallergic, anthelmintic, cytotoxicity and acute toxicity study of ethanolic extract of aerial parts of A. ilicifolius L. Significant inhibitory activity for allergic symptoms, differential leukocytes counts in blood, and for helminthic infestation were observed. The extract was also found to be toxic for brine shrimp nauplii but safe in acute toxicity test for in vivo administration. The outcome of the present study corroborated the traditional use of A. ilicifolius in allergic disease and in helminthic infestation. Further investigation would be required to establish the safety parameters through biochemical and histopathological studies, and to discover novel phytochemicals responsible for the antiallergic and anthelmintic activity of the aerial parts of Acanthus ilicifolius Linn.

\section{Abbreviations \\ DMSO: dimethyl sulfoxide; EEAl: Ethanolic extract of Acanthus ilicifolius L;; FIG: Figure; LC 50 : Lethal Concentration for 50\% test animal; MIN: minutes; OECD: Organization for Economic Co-operation and Development; P.O: per oral; PBS: Phosphate-buffered saline; S.D: Standard Deviation; TDI: Toluene 2, 4-diisocyanate; VS: versus \\ Acknowledgements \\ The authors would like to thank Rabindra Nath Acharyya and Suborna Rani, Pharmacy Discipline, Khulna University for their help during running the project. The authors are grateful to Pharmacy Discipline, Life Science School, Khulna University, for providing laboratory facilities to conduct the bioactivity studies. The authors are especially grateful to Wako Chemicals, Tokyo, Japan, for providing TDI and Cetirizine used in the test. The authors are grateful as well to the authority of Jahangirnagar University, Bangladesh for providing experimental mice.}

\section{Funding}

The project was supported by the B. Pharm laboratories' allocation of Pharmacy Discipline, Life Science School, Khulna University, Khulna-9208, Bangladesh.

\section{Availability of data and materials}

The datasets supporting the conclusions of this article are included within the article. 


\section{Authors' contributions}

The submitted research work was conducted in collaboration among the authors. The project was designed by SD, AKD and NNB. SD and PKS conducted the detail literature review and performed the phytochemical screening. PKS, SY, SP and MAAB have performed the extraction, antiallergic, anthelmintic, cytotoxic activities and acute toxicity tests. SD carried out the statistical analysis. Article was written by PKS, NNB and SD. Critical revision of the article was done by NNB and AKD. All authors read and approved the final manuscript.

\section{Ethics approval}

In our study, Organization for Economic Cooperation and Development guidelines for the care and use of animals were followed. Our study was approved by the research Ethics Committee of Pharmacy Discipline, Life Science School, Khulna University, Khulna-9208, Bangladesh. Three membered ethics committee consists of Dr. Ashis Kumar Das, Professor and Chairman of the committee (dasasish03@yahoo.com), Dr. Jamil Ahmed Shilpi (jamilshilpi@yahoo.com), Professor and Dr. Sheikh Jamal Uddin, Associate Professor (uddinsj@yahoo.com); Pharmacy Discipline, Life Science School, Khulna University, Khulna-9208, Bangladesh. The approval reference number is KU/PHARM/AEC/15/006/022.

\section{Consent for publication}

All co-authors have consented for the publication of this manuscript.

\section{Competing interests}

The authors declare that they have no competing interests.

\section{Publisher's Note}

Springer Nature remains neutral with regard to jurisdictional claims in published maps and institutional affiliations.

\section{Received: 5 June 2018 Accepted: 14 November 2018} Published online: 23 November 2018

\section{References}

1. Ghani A. Medicinal plants of Bangladesh with chemical constituents and uses. 2nd ed. Asiatic Society of Bangladesh: Dhaka; 2003.

2. Rai PK, Jaiswal D, Singh RK, Gupta RK, Watal G. Glycemic properties of Trichosanthes dioica leaves. Pharm Biol. 2008;46(12):894-9.

3. Asher MI, Montefort S, Bjorksten B, Lai CK, Strachan DP, Weiland SK, et al. Worldwide time trends in the prevalence of symptoms of asthma, allergic rhinoconjunctivitis, and eczema in childhood: ISAAC phases one and three repeat multicountry cross-sectional surveys. Lancet. 2006;368(9537):733-43.

4. Bousquet J, Van Cauwenberge P, Khaltaev N. Allergic rhinitis and its impact on asthma. J Allergy Clin Immunol. 2001;108(5):S147-334

5. Hossain E, Chandra G, Nandy AP, Mandal SC, Gupta JK. Anthelmintic effect of a methanol extract of Bombax malabaricum leaves on Paramphistomum explanatum. Parasitol Res. 2012;110(3):1097-102.

6. Slater JW, Zechnich AD, Haxby DG. Second-generation antihistamines. Drugs. 1999;57(1):31-47.

7. Brunton LL, Chabner BA, Knollmann BC. Goodman and Gilman's The Pharmacological Basis of Therapeutics. 12th ed. New York: McGrawHill Medical; 2011. p. 1444-59.

8. Dev S, Mizuguchi H, Das AK, Matsushita C, Maeyama K, Umehara H, et al. Suppression of histamine signaling by probiotic lac-B: a possible mechanism of its anti-allergic effect. J Pharmacol Sci. 2008;107(2):159-66.

9. Singh D, Aeri V. Phytochemical and pharmacological potential of Acanthus ilicifolius. J Pharm Bioallied Sci. 2013:5(1):17-20.

10. Lakshmi M, Rajalakshmi S, Parani M, Anuratha CS, Parida A. Molecular phylogeny of mangroves I. use of molecular markers in assessing the intraspecific genetic variability in the mangrove species Acanthus ilicifolius Linn. (Acanthaceae). Theor Appl Genet. 1997;94(8):1121-7.

11. Xie LS, Liao YK, Huang QF, Huang MC. Pharmacognostic studies on mangrove Acanthus ilicifolius. Zhongguo Zhong Yao Za Zhi. 2005;30(19): 1501-3.

12. Mani Senthil Kumar KT, Gorain B, Roy DK, Zothanpuia SSK, Pal M, et al. Anti-inflammatory activity of Acanthus ilicifolius. J Ethnopharmacol. 2008; 120(1):7-12.

13. Babu BH, Shylesh BS, Padikkala J. Antioxidant and hepatoprotective effect of Acanthus ilicifolius. Fitoterapia. 2001;72(3):272-7.
14. Subudhi HN, Choudhury BP, Acharya BC. Potential medicinal plants from Mahanadi Delta in the state of Orissa. J Econ Tax Bot. 1992;16:479-87.

15. Mastaller M, Hows JR, Matthew J, International W. Mangroves: the forgotten forest between land and sea. Medicinal uses. Kuala Lumpur: Tropical Press: 1997.

16. Bich DH, Trung DQ, Chuong BX, Dong NT, Dam DT, Hien PV, et al. The medicinal plants and animals of Vietnam. 1st ed. Hanoi: Hanoi Science and Technology Publisher; 2004. p. 497.

17. Chi W. The dictionary of Vietnamese medicinal plants. 1st ed. Hanoi: Hanoi Medicine Publisher; 1999. p. 886.

18. Kirtikar KR, Basu BD. Indian Medicinal Plants. 2nd ed. India: Basu LM Allahabad; 1999. p. 421-2. 1606-1609

19. Saranya A, Ramanathan T, Kesavanarayanan KS, Adam A. Traditional medicinal uses, chemical constituents and biological activities of a mangrove plant, Acanthus ilicifolius Linn. : A brief review. Am Eurasian J Agric Environ Sci. 2015;15(2):243-50.

20. Bandaranayke WM. Bioactivities, bioactive compounds and chemical constituents of mangrove plants. Wetl Ecol Manag. 2002;10(6):421-52.

21. Singh A, Dugga S, Suttee A. Acanthus ilicifolius Linn.-lesser known medicinal plants with significant pharmacological activities. Int J Phytomed. 2009;1(1): $1-3$.

22. Firdaus M, Prihanto AA, Nurdiani R. Antioxidant and cytotoxic activity of Acanthus ilicifolius flower. Asian Pac J Trop Biomed. 2013:3(1):17-21.

23. Zhang T, Tian Y, Jiang B, Miao M, Mu W. Purification, preliminary structural characterization and in vitro antioxidant activity of polysaccharides from Acanthus ilicifolius. LWT Food Sci Technol. 2014;56(1):9-14.

24. Gulcan HO, Kupeli E, Unlu S, Yesilada E, Sahin MF. 4-(5-chloro-2(3H)benzoxazolon-3-yl) Butanoic acid derivatives: synthesis, Antinociceptive and anti-inflammatory properties. Arch Pharm Pharm Med Chem. 2003;336(10): 477-82.

25. Wang Z, Chen Y, Zheng G, Yang C, Long S. Anti-inflammatory and analgesic effects of ilicifolius alkaloids a and its derivatives acetyl ilicifolius alkaloids a. Chin J Hosp Pharm Zhongguo Yiyuan Yaoxue Zazhi. 2011;31:807-10.

26. Sam J, Valentine JL. Preparation and properties of 2-benzoxazolinones. J Pharm Sci. 1969;58(9):1043-54.

27. Babu BH, Shylesh BS, Padikkala J. Tumour reducing and anticarcinogenic activity of Acanthus ilicifolius in mice. J Ethnopharmacol. 2002;79(1):27-33.

28. Chakraborty TD, Bhuniya D, Chatterjee M, Rahaman M, Singha D, Chatterjee $\mathrm{BN}$, et al. Acanthus ilicifolius plant extract prevents DNA alterations in a transplantable Ehrlich ascites carcinoma-bearing murine model. World J Gastroenterol. 2007;13(48):6538-48.

29. Ahmed K, Roy BK, Saha BK. Pharmacological evaluation of Acanthus ilicifolius L. root extract for asthmatic condition. Bangladesh J Scilnd Res. 2005;40: 195-202.

30. Kalaskar PS, Karande W, Bannalikar AS, Gatne MM. Antifungal activity of leaves of mangroves plant Acanthus ilicifolius against Aspergillus fumigatus. Indian J Pharm Sci. 2012;74(6):575-9.

31. Ravikumar S, Raja M, Gnanadesigan M. Antibacterial potential of benzoate and phenylethanoid derivatives isolated from Acanthus ilicifolius L. leaf extracts. Nat Prod Res. 2012;26(23):2270-3.

32. Venkataiah G, Ahmed MI, Reddy DS, Rejeena M. Anti-diabetic activity of Acanthus ilicifolius root extract in alloxan induced diabetic rats. Indo Am J of Pharm Res. 2013:3(11):9007-12.

33. Murty MSR, SolimabiKamat SY. Isolation of 2-benzoxazolinone from Acanthus ilicifolius. Indian J Pharm Sci. 1984:46:218-9.

34. Kapil A, Sharma S, Wahidulla S. Leishmanicidal activity of 2-benzoxazolinone from Acanthus ilicifolius in vitro. Planta Med. 1994;60(2):187-8.

35. Mani Senthil Kumar KT, Puia Z, Samanta SK, Barik R, Dutta A, Gorain B, et al. The gastroprotective role of Acanthus ilicifolius - a study to unravel the underlying mechanism of anti-ulcer activity. Sci Pharm. 2012;80(3):701-18.

36. Liu L, Fan H, Qi P, Mei Y, Zhou L, Cai L, et al. Synthesis and hepatoprotective properties of Acanthus ilicifolius alkaloid a and its derivatives. Exp Ther Med. 2013;6(3):796-802

37. Batta AK, Xu G, Honda A, Miyazaki T, Salen G. Stigmasterol reduces plasma cholesterol levels and inhibits hepatic synthesis and intestinal absorption in the rat. Metabolism. 2006;55(3):292-9.

38. Burg VK, Grimm HS, Rothhaar TL, Grösgen S, Hundsdörfer B, Haupenthal VJ, et al. Plant sterols the better cholesterol in Alzheimer's disease? A mechanistical study. J Neurosci. 2013;33(41):16072-87.

39. Ahmed MN, Sultana T, Azam MNK, Rahmatullah M. A preliminary antihyperglycemic and antinociceptive activity evaluation of a 
mangrove species Acanthus ilicifolius L. leaves in mice. Asian J Trad Med. 2014;9(6):143-9.

40. Kiem PV, Quang TH, Huong TT, le TH N, Cuong NX, Van Minh C, et al. Chemical constituents of Acanthus ilicifolius L. and effect on osteoblastic MC3T3E1 cells. Arch Pharm Res. 2008;31(7):823-9.

41. Sam J, Plampin JN. Benzoxazoles: Potent skeletal muscle relaxants. J Pharm Sci. 1964;53(5):538-44.

42. Tiwari KP, Minocha PK, Masood M. Acanthicifoline - a new alkaloid from Acanthus ilicifolius. Pol J Chem. 1980;54:857-8.

43. Minocha PK, Tiwari KP. Chemical constituents of Acanthus ilicifolius Linn. Pol J Chem. 1980;54(10):2089-90.

44. Kokpol U, Chittawong V, Miles DH. Chemical constituents of the roots of Acanthus ilicifolius. J Nat Prod. 1986:49(2):355-6.

45. Kanchanapoom T, Kamel MS, Kasai R, Picheansoonthon C, Hiraga Y, Yamasaki K. Benzoxazinoid glucosides from Acanthus ilicifolius. Phytochemistry. 2001;58(4):637-40.

46. Huo C, An D, Wang B, Zhao Y, Lin W. Structure elucidation and complete NMR spectral assignments of a new benzoxazolinone glucoside from Acanthus ilicifolius. Magn Reson Chem. 2005;43(4):343-5.

47. Wu J, Zhang S, Xiao Q, Li Q, Huang J, Long L, Huang L. Megastigmane and flavone glycosides from Acanthus ilicifolius. Pharmazie. 2003;58(5):363-4.

48. Wu J, Zhang S, Xiao Q, Li Q, Huang J, Long L, et al. Phenylethanoid and aliphatic alcohol glycosides from Acanthus ilicifolius. Phytochemistry. 2003; 63(4):491-5

49. Wu J, Zhang S, Huang J, Xiao Q, Li Q, Long L, Huang L. New aliphatic alcohol and (Z)-4- coumaric acid glycosides from Acanthus ilicifolius. Chem Pharm Bull. 2003:51(10):1201-3.

50. Kanchanapoom T, Kamel MS, Kasai R, Yamasaki K, Picheansoonthon C, Hiraga Y. Lignan glucosides from Acanthus ilicifolius. Phytochemistry. 2001; 56(4):369-72.

51. Wu J, Zhang S, Li Q, Huang J, Xiao Z, Long L. Two new cyclolignan glycosides from Acanthus ilicifolius. Chem Sci Z Naturforsch B. 2004;59(3): 341-4.

52. Huo C, Liang H, Tu G, Zhao Y, Lin W. A new 5, 11-epoxymegastigmane glucoside from Acanthus ilicifolius. Nat Prod Res. 2008;22(10):896-900.

53. Wu J, Huang J, Xiao Q, Zhang S, Xiao Z, Li Q, et al. Complete assignments of $1-\mathrm{H}$ and 13-C NMR data for ten phenylethanoid glycosides. Magn Reson Chem. 2004;42(7):659-62

54. Minocha PK, Tiwari KP. A triterpenoidalsaponin from roots of Acanthus ilicifolius. Phytochemistry. 1981;20(1):135-7.

55. Bechteler A, Pilkama A, Permana E, Poellath J, Prasanai K, Rahaju S et al. Coastal Zone Management in Southeast Asia. Case: Mangroves and Tsunami effects in Thailand. Proceedings of EU Asia Link FORRSA Course. Thailand, 2006. Accessed: 25 Jan 2015.

56. Husori DI, Sumardi, Tarigan H, Gemasih S, Ningsih SR. In vitro anthelmintic activity of Acanthus ilicifolius leaves extracts on Ascaridia galli and Pheretima posthuma. J App Pharm Sci. 2018;8(02):164-7.

57. Arora P, Ansari SH, Najmi AK, Anjum V, Ahmad S. Investigation of antiasthmatic potential of dried fruits of Vitis vinifera $L$. in animal model of bronchial asthma. Allergy Asthma Clin Immunol. 2016;12(1):42.

58. Harborne JB. Phytochemical Methods: A Guide to Modern Techniques of Plant Analysis. New Delhi: Springer (India) Pvt. Ltd; 1998.

59. OECD. Guidelines for testing of chemicals: guideline 425: acute Ora toxicity. Paris: The Organization of Economic Co-operation and Development; 2008. http://www.oecd.org/env/test-no-425-acute-oraltoxicity-up-and-down-procedure-9789264071049-en.htm. https://doi.org/ 10.1787/9789264071049-en.

60. Jain S, Bhatia G, Barik R, Kumar P, Jain A, Dixit VK. Antidiabetic activity of Paspalum scrobiculatum Linn. In alloxan induced diabetic rats. J Ethnopharmacol. 2010;127(2):325-8.

61. Tanaka K, Okamoto Y, Nagata Y, Nishimura F, Takeoka A, Hanada S, et al. A nasal allergy model developed in the Guinea pig by intranasal application of 2,4-toluene diisocyanate. Int Arch Allergy Appl Immunol. 1988;85(4):392-7.

62. Mahajan SG, Mali RG, Mehta AA. Effect of Moringa oleifera lam. Seed extract on toluene Diisocyanate-induced immune-mediated inflammatory responses in rats. J Immunotoxicol. 2007:4(2):85-96.

63. Dev S, Mizuguchi H, Das AK, Maeyama K, Horinaga S, Kato S, et al. Kujin Suppresses Histamine Signaling at the Transcriptional Level in Toluene 2, 4Diisocyanate-Sensitized Rats. J Pharmacol Sci. 2009;109(4):606-617. 4.

64. Abe $Y$, Takeda N, Irifune M, Ogino S, Kalubi B, Imamura I, et al. Effects of capsaicin desensitization on nasal allergy-like symptoms and histamine release in the nose induced by toluene diisocyanate in Guinea pigs. Acta Otolaryngol. 1992;112(4):703-9.

65. Nurul IM, Mizuguchi H, Shahriar M, Venkatesh P, Maeyama K, Mukherjee PK, et al. Albizia lebbeck suppresses histamine signaling by the inhibition of histamine $\mathrm{H} 1$ receptor and histidine decarboxylase gene transcriptions. Int Immunopharmacol. 2011;11(11):1766-72.

66. Smita J, Patil UK. Effect of Ipomea carnea Jacq. Flowers on hematological changes in toluene diisocyanate -induced inflammation in Wistar rats. Chin J Nat Med. 2014;12(3):161-6.

67. Tandon V, Pal P, Roy B, Rao HS, Reddy KS. In vitro anthelmintic activity of root-tuber extract of Flemingia vestita, an indigenous plant in Shillong, India. Parasitol Res. 1997:83(5):492-8.

68. Mahaldar K, Saifuzzaman M, Irin T, Barman AK, Islam MK, Rahman MM, Islam MA. Analgesic, anthelmintic and toxicity studies of Solanum violaceum Linn. Leaves Orient Pharm Exp Med. 2016;16(2):147-52.

69. Meyer BN, Ferrigni NR, Putnam JE, Jacobsen LB, Nichols DE, McLaughlin JL. Brine shrimp: a convenient general bioassay for active plant constituents. Planta Med. 1982;45(5):31-4.

70. Horn BR, Robin ED, Theodore J, Van Kessel A. Total eosinophil counts in the management of bronchial asthma. New England J Med. 1975;292(22):1152-5.

71. Noga $O, \operatorname{Hanf} G$, Kunkel G. Immunological and clinical changes in allergic asthmatics following treatment with omalizumab. Int Arch Allergy Immnol. 2003;131(1):46-52.

72. Andhare RN, Raut MK, Naik SR. Evaluation of antiallergic and antianaphylactic activity of ethanolic extract of Sanseveiria trifasciata leaves (EEST) in rodents. J Ethnopharmacol. 2012;142(3):627-33.

73. Naik SR, Bhagat S, Shah PD, Tare AA, Ingawale D, Wadekar RR. Evaluation of anti-allergic and anti-anaphylactic activity of ethanolic extract of Zizyphus jujube fruits in rodents. Rev Bras Farmacogn. 2013;23(5):811-8.

74. Arun LB, Arunachalam AM, Arunachalam KD, Annamalai SK, Kumar KA. In vivo anti-ulcer, anti-stress, anti-allergic and functional properties of gymnemic acid isolated from Gymnema sylvestreR Br. BMC Complement Altern Med. 2014;14(1):70.

75. Matsushita C, Mizuguchi H, Niino H, Sagesaka Y, Masuyama K, Fukui H. Identification of epigallocatechin-3-O-gallate as an active constituent in tea extract that suppresses transcriptional up-regulations of the histamine $\mathrm{H} 1$ receptor and interleukin-4 genes. J Tradit Med. 2008;25(5+6):133-42.

76. Vo TS, Ngo DH, Kim SK. Gallic acid-grafted chitooligosaccharides suppress antigen induced allergic reactions in RBL-2H3 mast cells. Eur J Pharm Sci. 2012:47(2):527-33.

77. Kato K, Yamashita S, Kitanaka S, Toyoshima S. Effect of gallic acid derivatives on secretion of Th1 cytokines and Th2 cytokines from anti CD3-stimulated spleen cells. Yakugaku Zasshi. 2001;121(6):451-7.

78. Kim SH, Jun CD, Suk K, Choi BJ, Lim H, Park S, et al. Gallic acid inhibits histamine release and pro-inflammatory cytokine production in mast cells. Toxicol Sci. 2006;91(1):123-31.

79. Wu Z, Turner DV, Oliveira DBG. IL-4 gene expression up-regulated by mercury in rat mast cells: a role of oxidant stress in IL-4 transcription. Int Immunol. 2001;13(3):297-304.

80. Gupta SS. Prospects and perspectives of natural plants products in medicine. Ind J Pharmacol. 1994;26:1-12

81. Goto C, Kasuya S, Koga K, Ohtomo H, Kagel N. Lethal efficacy of extract from Zingiber officinale (traditional Chinese medicine) or [6]-shogaol and [6]gingerol in Anisakis larvae in vitro. Parasitol Res. 1990;76(8):653-6.

82. Robinson RD, Williams LA, Linda JF, Terzy SI, Mansingh A. Inactivation of Strongyloides stercoralis larvae in vitro by six Jamaican plant extracts and three commercial anthelmintics. West Indian Med J. 1990;39(4):213-7.

83. Togo J, Santamarina MT, Peris D, Ubeira FM, Leiro SL, Sanmartin ML. In vitro effect of anthelmintics on Anisakis simplex survival. Jpn J Parasitol. 1992; 41(6):473-80.

84. Thompson DP, Geary TG. The structure and function of helminth surfaces. In: Marr J, Muller M, editors. Biochemistry and molecular biology of parasites. New York: Academic Press; 1995. p. 203-32.

85. Athnasiadau S, Kyriazakis I, Jackson F, Coop RL. Direct anthelmintic effects of condensed tannins towards different gastrointestinal nematodes of sheep: In vitro and in vivo studies. Vet Parasitol. 2001;99(3):205-19.

86. Patel J, Kumar GS, Qureshi MS, Jena PK. Anthelmintic activity of ethanolic extract of whole plant of Eupatorium odoratum. Int J Phytomed. 2010;2:127-32

87. Wang GX, Han J, Zhao LW, Jiang DX, Liu YT, Liu XL. Anthelmintic activity of steroidal saponins from Paris polyphylla. Phytomedicine. 2010;17(14):1102-5. 
88. Azando EV, Hounzangbe-Adote MS, Olounlade PA, Brunet S, Fabre N, Valentin $\mathrm{A}$, et al. Involvement of tannins and flavonoids in the in vitro effects of Newbouldia laevis and Zanthoxylum zanthoxyloides extracts on the exseathment of third-stage infective larvae of gastrointestinal nematodes. Vet Parasitol. 2011;180(3-4):292-7.

89. Mulla WA, Thorat VS, Patil RV, Burade KB. Anthelmintic activity of leaves of Alocasia indica Linn. Int J Pharm Tech Res. 2010;2(1):26-30.

90. Cruz ASP. Anthelmintic effect of Solanum lycocarpum in mice infected with Aspiculuris tetraptera. J Am Sci. 2008;4(3):75-9.

91. Suman A, Kumar DG, Kumar BD, Raj CR. Preliminary phytochemical investigation and chemical activity of Acacia suma (Roxb) barks. Int Res J Pharm. 2011;2:136-41.

92. Anderson JE, Goetz CM, McLaughlin JL, Suffness M. A blind comparison of simple bench top bioassays and human tumor cell cytotoxicities as antitumor prescreens. Phytochem Anal. 1991;2(3):107-11.

93. Borowitz $J$, McLaughlin JL. Evidence for calcium channels in brine shrimp: diltiazem protects shrimp against cadmium. Bull Environ Contam Toxicol. 1992;48(3):435-40.

94. Abdullahi AL, Agho MO, Amos S, Gamaniel KS, Wambebe C. Antidiarrhoeal activity of the aqueous extract of Terminalia avicennoides roots. Phytother Res. 2001;15(5):431-4.

95. Silva TM, Nascimento RJ, Batista MM, Agra MF, Camara CA. Brine shrimp bioassay of some species of Solanum from Northestern Brazil. Rev Bras Pharmacogn. 2007;17(1):35-8.

96. Hossain MM, Mondal M, Hossain MP, Uddin MS, Uddin N, Hasan MM, et al In vitro antioxidant, brine shrimp lethality and antimicrobial activities of methanol and petroleum ether extracts of Cassia renigera fruit. Food Measure. 2015;9(1):68-75

97. Deciga-Campos M, Rivero-Cruz I, Arriaga-Alba M, Castaneda-Corral G, Angeles-Lopez GE, Navarrete A, et al. Acute toxicity and mutagenic activity of Mexican plants used in traditional medicine. J Ethnopharmacol. 2007; 110(2):334-42.

98. Ozcelik B, Kartal M, Orhan I. Cytotoxicity, antiviral and antimicrobial activities of alkaloids, flavonoids, and phenolic acids. Pharm Biol. 2011;49(4):396-402.

99. Balasundaram N, Sundaram K, Samman S. Phenolic compounds in plants and Agri-industrial by-products. Antioxidant activity, occurrence and potential uses. Food Chem. 2006;99(1):191-203.

100. Ksouri R, Falleh H, Megdiche W, Trabelsi N, Mhamdi B, Chaieb K, et al. Antioxidant and antimicrobial acivities of the edible medicinal halophyte Tamarix gallica L. and related polyphenolic constituents. Food Chem Toxicol. 2009;47(8):2083-91.

101. Chang YC, Tai KW, Huang FM, Huang MF. Cytotoxic and nongenotoxic effects of phenolic compounds in human pulp cell cultures. J Endod. 2000; 26(8):440-3.

\section{Submit your manuscript to a SpringerOpen ${ }^{\circ}$ journal and benefit from:}

- Convenient online submission

Rigorous peer review

- Open access: articles freely available online

- High visibility within the field

- Retaining the copyright to your article

Submit your next manuscript at $\boldsymbol{\nabla}$ springeropen.com 